\title{
Comparing Online and Paper Exams: Performances and Perceptions of Saudi Students
}

\author{
Majdi Al-Qdah and Islam Ababneh
}

\begin{abstract}
This paper investigates the effects of online exams on students' achievements and the students' perceptions of online and paper exams after taking an experimental online and paper based exams. Carefully designed exams that included various types of questions were attempted by male students in the faculty of computers and information technology and female students in the faculty of Education and Arts. The Moodle Quiz tool was used to design and conduct the online exams. The results of the online exams were compared with similar designed paper based exams. The students' performances in exams were measured in each question type (MCQ, TF, short, essay, numerical, and descriptive). Surprisingly, the mean and standard deviation statistical results were found to be similar between both paper based and online exams in the MCQ, TF, and numerical type of questions; while the essay questions results indicated that the students preferred to answer on paper rather than type on the computer screen. In the followed survey about their experiences with both exams, the students indicated to prefer certain aspects of online exams such as automatic results and feedback.
\end{abstract}

Index Terms-Paper exams, online exams, experimental exams, Moodle quiz, question types.

\section{INTRODUCTION}

Examinations improve teaching by helping the teacher's planning and consistent student preparation. Examinations are not limited to measure educational or societal objectives and needs but incorporate in a way of coping with the educational system [1]. Exams generally determine the extent to which educational objectives are achieved as well as the extent to which educational institutions serve the needs of the community and society [2]. Rehmani (2003) explained that 'examinations play a significant role in determining what goes on in the classroom in terms of what, and how teachers teach and students learn and can have impact on both teaching and learning [3]. The rapid advancement of Information and Communication Technologies (ICT) in teaching and learning has shifted the paradigm from paper-pencil-based to computer-based system of examinations [4]. There are many names and forms to computer based exams: Computer Assisted Testing, Computerized Assessment, Computer Based Testing (CBT), Computer Aided Assessment (CAA), Computer Based Assessment (CBA), Online Assessment, E-Assessment and Web-Based assessment and others. Bodmann and Robinson (2004) contended that Technology based assessment provide opportunities to measure complex

Manuscript received August 10, 2015; revised November 4, 2015.

Majdi Al-Qdah and Islam Ababneh are with University of Tabuk, Tabuk, KSA (e-mail: mqdah@ut.edu.sa, iababneha@ut.edu.sa). form of knowledge and reasoning that is not possible to engage and assess through traditional methods [5]. According to Conole and Warburton (2005) explained that CAT items are written to test particular levels of ability they have the potential to deliver more accurate and reliable results than traditional tests [6]. Al-Mashaqbeh, I.F and Al- Hamad in the department of computer education in Jordan showed that there was a positive perception towards adopting online exams. They measured students' perceptions toward the use of an online exam as an assessment tool on university campus within a Decision Support System Course at Al al Bayt University [7]. Mazzeo, Druesne, Raffeld, Checketts, \& Muhlstein (1991) showed that paper-based test scores were greater than computer-based test scores for both mathematics and English CLEP tests [8]; although studies of Schaeffer, Reese, Steffen, McKinley, \& Mills (1993) have reported no difference between computer and paper-based tests [9].

This paper presents the results of comparative study between paper based and online exams conducted on a group of Tabuk university students, who had no prior experience of taking online exams, in the region of Tabuk, Saudi Arabia. In this paper, the name "online exams" is adopted to refer to an exam that is computer based with connection to a network in the server/client setup, where the student sits on the client side and the exam is located on the server side (that can be outside of the local university campus). The paper exam is the traditional paper and pen exam that requires students to write their answers. First, this research paper gives the statistical results of conducting two online exams and similar two paper exams for two groups of people. Then, it gives the results of a survey about students' perception of online exams and paper based exams: which type is more effective evaluation tool and which type is more satisfying to the students. The significance of this study is that it took place in a university/faculty that is only experimentally starting to selectively implement online exams for possible full implementation in the university with participants who were seeing such method of evaluation for the very first time. The overall results of this research should give the administration at the University of Tabuk some good knowledge based on the students' exam results and the results of the surveys on future directions of implementing online exams (especially for final exams) and the difficulties that surround such a step; especially, when completely replacing paper exams with online exams.

\section{METHODS}

Fifty male undergraduate students in their third or fourth year levels in the Faculty of Computers and Information Technology with majors in Computer Science or Information Technology and fifty female students in the faculty of 
Education and Arts with English major in their fourth year were given both a paper based exam and a similar online exam covering the content of some enrolled subjects in the fall/spring semesters of the year 2014/2015. The computer Science or Information Technology major students were very familiar with use of computer systems and the Internet while most of the English major female students could fairly use the examination system and had to be helped with logging in and starting the exam.

The paper exams were given inside normal classroom venues with normal exam setup: adequately spacing the students and including two forms of the question paper to reduce/eliminate cheating cases. The online exams were conducted inside computer lab rooms during designated lab hours with the researcher being present inside the room monitoring and supervising the exam. The students identities were verified before taking both types of exams using their national identity cards and the teacher's own familiarity with the students.

The Moodle learning system quiz tool was used for examination. Moodle is an interactive learning management environment that is used by many institutions all over the world. It has features to upload various learning resources and assign activities for students including online exams. It uses the Client/Server model where the learning material is on a web server and is accessed through a browser on a client side. Moodle exams allow options of timing and IP strict access to exams, shuffling of the questions, general and specific feedback to students, automatic grading, and other interesting options.

Both online and paper exams that were attempted by the computer major male students included five types of equal difficulty and similar questions: T/F, MCQ, Short answer, Matching, and Calculated types while the English major female students attempted online and paper exams with only four type of questions: T/F, MCQ, Short answer, and Matching types. The online exams had options such as randomizing the order of questions and shuffling within each question, varying numerical values in the calculated questions from one student to another, opening a new page with each question ...etc.

Then, the online exams were automatically evaluated and the students viewed their results just after each exam with some general and question specific feedbacks while the paper exams were manually graded and handed to the students in the next class sessions.

A questionnaire was then distributed to each one of the students after completing both the paper based and the online based exams. The purpose of the questionnaire was to gauge the students satisfaction and experience with both exams, attitudes toward the exams, differences between the two exams, easiness or difficulty of both exams, usefulness of the exams, technology effects on examinations, which type of exam provides better assessment results, which of the exams was more difficult to take, and which type of exam saves more time according to the students own opinions.

\section{RESULTS AND DISCUSSIONS}

Similar statistical results (averages and standard deviations) of the paper and online exams were obtained for both the Computer Science/Information Technology major male and English major female students and are given in Table I and Table II, respectively. The tables show that there is no significant differences between the averages and standard deviations of the online and paper exams.

TABLE I: AVERAGES AND STANDARD DEVIATIONS (MALES)
\begin{tabular}{|l|l|l|}
\hline Metric & Online Exam & Paper Exam \\
\hline Average & $66 \%$ & $62 \%$ \\
\hline Std & $12.43 \%$ & $11.82 \%$ \\
\hline
\end{tabular}

TABLE II: AVERAGES AND STANDARD DEVIATIONS (FEMALES)

TABLE II: AVERAGES AND STANDARD DEVIATIONS (FEMALES)
\begin{tabular}{|l|l|l|}
\hline Metric & Online Exam & Paper Exam \\
\hline Average & $70 \%$ & $68 \%$ \\
\hline Std & $10.50 \%$ & $10.71 \%$ \\
\hline
\end{tabular}

The performance of the Computer Science/Information Technology male students in the online and paper based exams in each question are given in Table III and Table IV, respectively. The tables give percentages of correct and wrong answers to questions included in both exams in each type of a question.

TABLE III: ONLINE EXAm STATistics (MALeS)

\begin{tabular}{|l|l|l|}
\hline Questions & Correct (\%) & Wrong (\%) \\
\hline Multiple choice & $56 \%$ & $44 \%$ \\
\hline True/False & $60 \%$ & $40 \%$ \\
\hline Short answer & $21 \%$ & $79 \%$ \\
\hline Matching & $80 \%$ & $20 \%$ \\
\hline Calculated & $25 \%$ & $75 \%$ \\
\hline
\end{tabular}

TABLE IV: PAPER EXAM STATISTICS (MALES)

\begin{tabular}{|l|l|l|}
\hline Questions & Correct (\%) & Wrong (\%) \\
\hline Multiple choice & $53 \%$ & $47 \%$ \\
\hline True/False & $56 \%$ & $44 \%$ \\
\hline Short answer & $21 \%$ & $79 \%$ \\
\hline Matching & $80 \%$ & $20 \%$ \\
\hline Calculated & $73 \%$ & $27 \%$ \\
\hline
\end{tabular}

From the tables above, the Computer Science/ Information Technology male students performed better on MCQ, T/F and Matching questions than short answer and calculated question types in both online and paper exams. Surprisingly, the students performed similarly in the online and paper exams in four types of questions (MCQ, T/F, Matching, and short answer); but they performed better in the calculated questions on paper as partial credit was given in the paper exam but not in the online exam.

The performance of the English major female students in the online and paper based exams in each question are given in Table V and Table VI, respectively. The tables give percentages of correct and wrong answers to the four question types in both the online and paper exams.

TABLE V: ONLINE EXAM STATISTICS (FEMALES)

\begin{tabular}{|l|l|l|}
\hline Questions & Correct (\%) & Wrong (\%) \\
\hline Multiple choice & $68 \%$ & $32 \%$ \\
\hline True/False & $60 \%$ & $40 \%$ \\
\hline Short answer & $77 \%$ & $23 \%$ \\
\hline Matching & $85 \%$ & $15 \%$ \\
\hline
\end{tabular}

TABLE VI: PAPER EXAM STATISTICS (FEMALES)

\begin{tabular}{|l|l|l|}
\hline Questions & Correct $(\%)$ & Wrong (\%) \\
\hline Multiple choice & $67 \%$ & $33 \%$ \\
\hline True/False & $58 \%$ & $42 \%$ \\
\hline Short answer & $70 \%$ & $30 \%$ \\
\hline Matching & $80 \%$ & $20 \%$ \\
\hline
\end{tabular}


The two tables above indicate that the English major female students performed similarly in the online and paper based exams. Also, the students performed similarly in all four types of questions even in the short answer type. Most likely, the English female students had better English skills than the computer major male students and could express their answers using correct English sentences on paper as well as type their answers on computer screens.

Therefore, based on these initial results the online exams can be regarded as a fair and a comparable tool to paper exams. Online exams can equivalently evaluate students using MCQ, T/F, and matching types of questions but a special care should be taken when designing exams with complex types of questions that require students to solve equations or elaborate using some sentences; i.e., calculation question types. Many students who attempted the exams lacked good math skills and preferred to solve problems on paper. Thus, calculation questions in online exams may require a scratch paper for students to solve problems before filling in the answers. Also, the male students had problems with short answer questions in both types of exams and that could have been due to lack of good English skills as the short answer questions required the students to write/type the answer. Most students (computer and English majors) completed the online exams in 30\% less time than the paper based exams. With regard to gender, most likely that it did not play a major factor in the results of this study but rather good English skills of some students contributed to them answering questions that required writing/typing the answers.

Technically, some of the students had problems to login into the system prior to the exam; also, some students had issues with network connection while taking the exam but managed to reconnect to the network and resume the online exam. This brings to mind technology failures (computers, networks, light...etc.) during the conduct of online exams; and such issues require the examination administering body to make sure that backup light generators, backup computer systems, and some technical people be available in the exam venues in such cases. Also, the students' answers must be frequently and automatically saved so that the students could resume their examination once technical issues are resolved without any loss of data. Furthermore, challenges of security and students' identification should be resolved at system and administration levels.

Next, the results of the surveys, shown in Table VII and Table VIII, indicate that all the students slightly preferred paper type exams; but many students preferred some options of online examination such as automatic exam results, automatic feedback, less time to take the exam. The computer major students preferred to write and read from a paper and not type and read from computer screens while the English major students welcomed typing on computer screens. Some students explained orally that reading from the computer was more stressful on their eyes. Dillon (1994) explained that reading from a computer screen was on average $20 \%$ to $30 \%$ slower than from paper [10]. Surprisingly, more students answered that online exams were more relaxing and less tiring. High percentage of students thought online exams helped reduce/eliminate cheating but they thought online exams were more expensive to conduct and administer. Overall, some features that the survey inquired about and other available ones in online exams designing tools: instant results, feedback after answers, multiple retakes of the exam, test question banks...etc. can be utilized by teachers preparing such exams to enhance the students' online examination experience.

\begin{tabular}{|c|c|c|c|}
\hline Online Exams & $\%$ & Paper Exams & $\%$ \\
\hline I prefer online exams & 40 & $\begin{array}{l}\text { I prefer paper based } \\
\text { exams }\end{array}$ & 60 \\
\hline $\begin{array}{l}\text { Online exams are more } \\
\text { readable }\end{array}$ & 45 & $\begin{array}{l}\text { Paper exams are more } \\
\text { readable }\end{array}$ & 55 \\
\hline $\begin{array}{l}\text { I prefer to type on the } \\
\text { screen (Online exams) }\end{array}$ & 35 & $\begin{array}{l}\text { I prefer to write on } \\
\text { paper (Paper exams) }\end{array}$ & 65 \\
\hline $\begin{array}{l}\text { Online exams are less } \\
\text { tiring }\end{array}$ & 61 & $\begin{array}{l}\text { Paper exams are less } \\
\text { tiring }\end{array}$ & 39 \\
\hline $\begin{array}{l}\text { Online exams are more } \\
\text { relaxing }\end{array}$ & 57 & $\begin{array}{l}\text { Paper exams are more } \\
\text { relaxing }\end{array}$ & 43 \\
\hline $\begin{array}{l}\text { I like to get results right } \\
\text { after exam }\end{array}$ & 64 & $\begin{array}{l}\text { I like to get results at a } \\
\text { later time }\end{array}$ & 36 \\
\hline $\begin{array}{l}\text { I like automatic } \\
\text { feedback }\end{array}$ & 80 & $\begin{array}{l}\text { I do not like automatic } \\
\text { feedback }\end{array}$ & 20 \\
\hline $\begin{array}{l}\text { Online exams } \\
\text { reduce/eliminate } \\
\text { cheating }\end{array}$ & 75 & $\begin{array}{l}\text { Paper exams } \\
\text { reduce/eliminate } \\
\text { cheating }\end{array}$ & 25 \\
\hline $\begin{array}{l}\text { Online exams save } \\
\text { time }\end{array}$ & 70 & Paper exams save time & 30 \\
\hline $\begin{array}{l}\text { Online exams are more } \\
\text { expensive }\end{array}$ & 73 & $\begin{array}{l}\text { Paper exams are more } \\
\text { expensive }\end{array}$ & 27 \\
\hline
\end{tabular}

TABLE VIII: COMPARATIVE SURVEY STATISTICS (FEMALES)

\begin{tabular}{|c|c|c|c|}
\hline Online Exams & $\%$ & Paper Exams & $\%$ \\
\hline I prefer online exams & 45 & $\begin{array}{l}\text { I prefer paper based } \\
\text { exams }\end{array}$ & 55 \\
\hline $\begin{array}{l}\text { Online exams are more } \\
\text { readable }\end{array}$ & 48 & $\begin{array}{l}\text { Paper exams are more } \\
\text { readable }\end{array}$ & 52 \\
\hline $\begin{array}{l}\text { I prefer to type on the } \\
\text { screen (Online exams) }\end{array}$ & 43 & $\begin{array}{l}\text { I prefer to write on } \\
\text { paper (Paper exams) }\end{array}$ & 57 \\
\hline $\begin{array}{l}\text { Online exams are less } \\
\text { tiring }\end{array}$ & 60 & $\begin{array}{l}\text { Paper exams are less } \\
\text { tiring }\end{array}$ & 40 \\
\hline $\begin{array}{l}\text { Online exams are more } \\
\text { relaxing }\end{array}$ & 57 & $\begin{array}{l}\text { Paper exams are more } \\
\text { relaxing }\end{array}$ & 43 \\
\hline $\begin{array}{l}\text { I like to get results right } \\
\text { after exam }\end{array}$ & 70 & $\begin{array}{l}\text { I like to get results at a } \\
\text { later time }\end{array}$ & 30 \\
\hline $\begin{array}{l}\text { I like automatic } \\
\text { feedback }\end{array}$ & 75 & $\begin{array}{l}\text { I do not like automatic } \\
\text { feedback }\end{array}$ & 25 \\
\hline $\begin{array}{l}\text { Online exams } \\
\text { reduce/eliminate } \\
\text { cheating }\end{array}$ & 64 & $\begin{array}{l}\text { Paper exams } \\
\text { reduce/eliminate } \\
\text { cheating }\end{array}$ & 36 \\
\hline $\begin{array}{l}\text { Online exams save } \\
\text { time }\end{array}$ & 55 & Paper exams save time & 45 \\
\hline $\begin{array}{l}\text { Online exams are more } \\
\text { expensive }\end{array}$ & 61 & $\begin{array}{l}\text { Paper exams are more } \\
\text { expensive }\end{array}$ & 39 \\
\hline
\end{tabular}

Finally, this study was conducted in a university that is only starting to experiment with giving online computer exams in fundamental courses with only T/F and MCQ types of questions and in a limited number of faculties. The University of Tabuk traditional paper exams for distance education programs are usually multiple choice questions or true/false questions that have always been exhaustive to conduct on both students and lecturers as they require space and people for the large number of students who enroll in the program. Therefore, it is accommodating that online exams can potentially save time and effort if conducted appropriately for 
the distance education program, which might require minimal training on needed computer and software skills for both the students and teaching staff.

\section{CONCLUSION}

The type of exam (paper or online) and the type of questions used in exams usually do not play a significant part in the performance of students but rather students' preparations and amount of study were the major factors in obtaining positive results in the experimental exams conducted. It was evident that good students performed well either in paper exams or in online exams while poor students had difficulties in both types of exams. Also, some features of online exams such as automatic results and feedback are preferred by students and maybe included in practice exams to improve students understanding of the subject material. In order to substantiate the results of this study, a larger number sample of students should be used including students with various majors (science and arts) and from both genders. Also, the study must be extended to few faculties and numerous subjects with male and female participants in order to be conclusive and in order for the results to be indicative of a larger sample of students.

\section{ACKNOWLEDGMENT}

The author would like to acknowledge financial support of this work from the Deanship of Scientific Research (DSR), University of Tabuk, Tabuk, Saudi Arabia, under grant no. S/0100/1436

\section{REFERENCES}

[1] A. Havens. Examinations and learning: an activity - Theoretical analysis of the relationship between assessment and learning. (2002). [Online]. Available: http://www.leeds.ac.uk/educol/documents/00002238.htm

[2] J. H. Shah, "Validity and credibility of public examinations in Pakistan," Thesis Submitted for the Degree of Ph. D., Department of Education, Islamia University Bahawalpur, Pakistan, 2002.
[3] A. Rehmani. (2003). Impact of public examination system on teaching and learning in Pakistan. [Online]. Available: http://www.aku.edu/AKUEB/pdfs/pubexam.pdf

[4] O. Uysal and A. Kuzu, "A thesis proposal: quality standards of online higher education in turkey. Internationalization and the role of university networks," in Proc. the 2009 EMUNI Conference on Higher Education and Research, Potorož, Slovenia, September 25-26.

[5] S. M. Bodmann and D. H. Robinson, "Speed and performance differences among computer-based and paper-pencil tests," Journal of Educational Computing Research, vol. 31, no. 1, pp. 51-60, 2004.

[6] G. Conole and B. Warburton, "A Review of computer assisted assessment," ALT-J, Research in Learning Technology, vol. 13, no. 1, pp. 17-31, 2005.

[7] I. F. Al-Mashaqbeh and A. Al Hamad, "Student's perception of an online exam within the decision support system course at Al al Bayt University," Conference Publication, May 7-10, 2010, pp. 131-135.

[8] J. Mazzeo, B. Druesne, P. C. Raffeld, K. T. Checketts, and A. Muhlstein, "Comparability of computer and paper-and-pencil scores for two CLEP general examinations," College Board report No. 91-5. (Available from ERIC: ED 344 902), 1991.

[9] G. A. Schaeffer, C. M. Reese, M. Steffen, R. L. McKinley, and C. N. Mills, "Field test of a computer-based GRE general test," ETS Research Report \#93-07, 1993.

[10] A. Dillon, "Designing usable electronic text: Ergonomics aspects of human information usage," London: Taylor \& Francis, 1994.

Majdi Al-Qdah was born in Irbid, Jordan and obtained his bachelor's degree in electrical engineering from the University of Houston, Houston, TX, U.S.A. in the year 1994 and his masters and $\mathrm{PhD}$ in computer engineering from Universiti Putra Malaysia, KL, Malaysia in the years 2000, 2006 respectively.

He has worked in various academic and industrial institutions globally in the U.S.A, Malaysia, Canada, Jordan, and Saudi Arabia. Currently, he is an assistant professor in the University of Tabuk, Tabuk, KSA since the year 2013. He has research interests in e-learning tools, data hiding and watermarking, cryptography, and general image processing techniques.

Islam F. Ababneh was born in Irbid, Jordan and obtained her bachelor's degree in English literature from Yarmouk University in Jordan in the year 2000 and her MA degree from Universiti Putra Malaysia in the year 2003 and $\mathrm{PhD}$ in applied linguistics in the year 2010 from Universiti Kebanqsaan Malaysia. Also, Islam obtained a diploma in university teaching while living in Canada.

She obtained advanced English and French language training from Canada in addition to working as an assistant researcher at Saint Thomas University in /Fredericton, NB, Canada. She has research interests in children education, comparative Arabic and English literacy within local Arab communities, and causes of English translational errors made by Arab natives. 